\title{
EXPERIMENTAL STUDY OF DENDRIMER-BASED NANOPARTICLES WITH RGD-PEPTIDE FOR ANTICANCER RADIONUCLIDE THERAPY
}

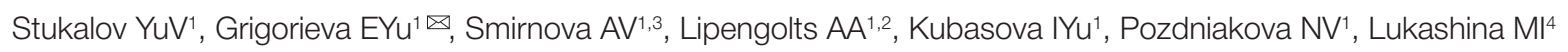 \\ ${ }^{1}$ Blokhin National Medical Research Center of Oncology, Moscow \\ 2 Burnazyan Federal Medical Biophysical Center, Moscow \\ ${ }^{3}$ Loginov Moscow Clinical Scientific Center, Moscow \\ ${ }^{4}$ Dmitry Rogachev National Research Center of Pediatric Hematology, Oncology and Immunology, Moscow
}

\begin{abstract}
Radionuclide therapy (RNT) is an effective modality for treating multiple metastases in patients with cancer. The list of malignancies that can be managed with RNT expands with the arrival of novel tumoritropic radiopharmaceuticals (RP). A versatile delivery platform capable of carrying various therapeutic and diagnostic radionuclides, as well as vector molecules needed to achieve sufficient specificity to tumor cells and ensure therapeutic efficacy may hold great promise for radiation therapy. The aim of this work was to assess the performance of a delivery system based on the original dendrimer. The dendrimer demonstrated low toxicity in mice $\left(L_{50}\right.$ was $779 \pm 111 \mathrm{mg} / \mathrm{kg}$ ). To study the specificity of the dendrimer to tumor cells and its therapeutic efficacy, we used a nanoplatform (NP) composed of the dendrimer itself, the RGD peptide and ${ }^{188} \mathrm{Re}\left({ }^{188} \mathrm{Re}-\mathrm{NP}\right)$. Lewis lung carcinoma LLC1 was used as a tumor model. The biodistribution analysis revealed that the compound effectively accumulated in the tumor demonstrating a tumor-to-normal ratio $>1$ (relative to healthy organs and tissues) and retention time of at least 6 hours. Injections of $185 \mathrm{MBq} / \mathrm{kg}{ }^{188} \mathrm{Re}-\mathrm{NP}$ caused a statistically significant inhibition of tumor growth $(p<0.05)$ by day 7 following the injection ( $\mathrm{T} / \mathrm{C}=5 \%$ ), which remained stable for 6 days. Our findings suggest that the proposed dendrimer is a promising platform for RP delivery.
\end{abstract}

Keywords: dendrimer, RGD peptide, ${ }^{188} \mathrm{Re}$, radionuclide therapy, biodistribution, research in animals, transplanted tumor model

$\bowtie$ Correspondence should be addressed: Elena Yu. Grigorieva

Kashirskoe shosse 24, Moscow, 115478; grig-elen11@mail.ru

Received: 12.09.2018 Accepted: 11.10.2018

DOI: $10.24075 /$ brsmu.2018.089

\section{ЭКСПЕРИМЕНТАЛЬНЫЕ ИССЛЕДОВАНИЯ ДЕНДРИМЕРНОЙ НАНОКОНСТРУКЦИИ С RGD-ПЕПТИДОМ ДЛЯ РАДИОНУКЛИДНОЙ ТЕРАПИИ ОНКОЛОГИЧЕСКИХ ЗАБОЛЕВАНИЙ}

Ю. В. Стукалов ${ }^{1}$, Е. Ю. Григорьева ${ }^{凶}$, А. В. Смирнова ${ }^{1,3}$, А. А. Липенгольц ${ }^{1,2}$, И. Ю. Кубасова ${ }^{1}$, Н. В. Позднякова М. И. Лукашина ${ }^{4}$

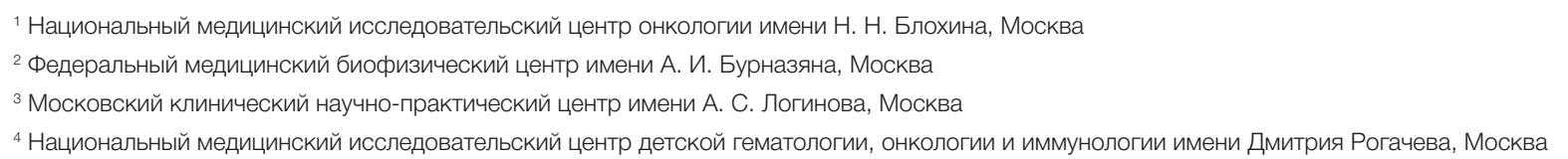

Национальный медицинский исследовательский центр детской гематологии, онкологии и иммунологии имени Дмитрия Рогачева, Москва

Радионуклидная терапия (РНТ) является эффективным методом лечения множественных метастазов злокачественных опухолей. Расширение номенклатуры злокачественных новообразований, для которых возможно применение РНТ, происходит за счет создания новых туморотропных радиофармацевтических препаратов (РФП). Перспективно создание РФП на основе универсальной транспортной платформы, которая может быть модисицирована различными терапевтическими и диагностическими радионуклидами, а также векторными молекулами для достижения требуемой специфичности к опухолям и терапевтической эффективности. Целью работы было оценить в качестве такой транспортной платформы конструкцию на основе оригинального дендримера. Исследование на мышах показало его низкую токсичность (ЛД исследовали на примере наноконструкции (HK) из дендримера, RGD-пептида и радионуклида ${ }^{188} \mathrm{Re}\left({ }^{188} \mathrm{Re}-\mathrm{HK}\right)$. B качестве опухолевой модели использовали мышиную карциному легкого Льюиса LLC1. Данные биораспределения предложенной НК показали ее эффективное накопление в опухоли с коэффициентом дифференциального накопления более 1 по отношению к основным органам и тканям и временем удержания в опухоли не менее 6 ч. Введение ${ }^{188} \mathrm{Re}-\mathrm{HK}$ в дозе 185 МБК/Кг мышам с подкожно трансплантированной опухолью статистически достоверно $(p<0,05)$ способствовало торможению роста опухоли к 7-м суткам после введения до Т/C = 5\%, сохраняющемуся в течение 6 суток. Проведенные исследования показали перспективность исследованного дендримера как транспортной платформы для РНТ.

Ключевые слова: дендример, RGD-пептид, ${ }^{188} \mathrm{Re}$, радионуклидная терапия, биораспределение, исследование на животных, перевивные опухолевые модели

$\bowtie$ Для корреспонденции: Елена Юрьевна Григорьева

Каширское шоссе, д. 24, г. Москва, 115478; grig-elen11@mail.ru

Статья получена: 12.09.2018 Статья принята к печати: 11.10.2018

DOI: $10.24075 /$ vrgmu.2018.089 
The use of drugs that can effectively and selectively accumulate in malignant tissue is a key to the success of radionuclide, neutron capture and photon activation therapies [1]. Recently, there has been a burgeoning interest in dendrimers [2-6], the spherical molecules sized 2-10 nm that have a large number of functional groups in their outer shell and, therefore, can be conjugated to a wide range of different molecules. This facilitates creation of targeted drug delivery platforms by attaching a tumor-specific agent and a tumoricidal or a diagnostic agent to the dendrimer. Previously, we demonstrated the feasibility and promise of this approach for the therapy and diagnosis of cancer [7-8]. Such platforms can exploit the affinity of cancer cell receptors to a number of low molecular weight compounds. For example, dendrimers functionalized with $\beta$-estradiol have been shown to effectively accumulate in transplanted breast adenocarcinoma cells (Ca755) [9]. In the study below, the role of a target-specific component of a tested dendrimer-based platform was played by the RGD-peptide capable of biding to the integrins present on the surface of cancer cells [10-17].

This work aimed to investigate the feasibility of using the original dendrimer-based nanoplatform in radiation therapy and cancer diagnostics in a series of in vivo experiments.

\section{METHODS}

The original nanoplatform (NP) consisted of a first-generation dendrimer covalently conjugated to safranin, which binds sodium perrhenate, and a tumor-specific RGD peptide. The dendrimer itself was previously described in [7]. Fig. 1 shows the NP; its structure was confirmed by nuclear magnetic resonance spectroscopy.

The radionuclide ${ }^{188} \mathrm{Re}$ with a half-life of 17 hours was used as a therapeutic agent. Its decay is accompanied by the emission of $\beta$-radiation with energies of $2.12 \mathrm{MeV}$ producing the tumoricidal effect and $\gamma$-radiation with energies of $155 \mathrm{keV}$ (15.2\%) detectable by a $\gamma$-camera that records distribution of a radiopharmaceutical agent in a patient's body 18-23]. The GREN-1 ${ }^{188} \mathrm{~W} /{ }^{188} \mathrm{Re}$ generator (Leipunsky Institute of Physics and Power Engineering, Russia) used in this study was generating ${ }^{188} \mathrm{Re}$ over the course of 4-6 months [24]; therefore, the studied compounds could be labeled with ${ }^{188} \mathrm{Re}$ immediately before use.

Radiolabeling was performed by combining the studied NP and ${ }^{188} \mathrm{Re}$ sodium perrhenate eluted from the generator. The amount of ${ }^{188} \mathrm{RE}-\mathrm{NP}$ in the working solution was calculated based on the molarity of the introduced ${ }^{188} \mathrm{Re}\left(1 \mathrm{MBq}{ }^{188} \mathrm{Re}-\right.$ $0.00015 \mathrm{nM})$. To make sure every ${ }^{188}$ Re was bound, NP were taken at 100-fold excess. The isotope was added to the studied compounds ex tempore. Nuclear magnetic resonance spectra were recorded by the WH-360 spectrometer (Bruker; Germany) operating at $360 \mathrm{MHz}$. Thin-layer chromatography was performed using Si 60-coated plates (particle size of 5-17 $\mu \mathrm{m}$ ) (Fluka; USA). Chromatograms were developed in iodine vapor.

Due to the high costs of the RGD peptide, acute toxicity of ${ }^{188}$ RE-NP was inferred from the toxicity of the unmodified dendrimer measured in healthy male Balb/c mice weighing 19-21 g. (Stolbovaya nursery of the Research Center for Biomedical Technologies, Russia). The experiments were conducted in full compliance with ethical principles and guidelines for animal research [25].

The animals were kept in the conventional vivarium under natural light conditions. For the experiment, the mice were distributed into 10 groups of 6 . Each group consisted of animals of the same age. The dendrimer was dissolved in $0.9 \%$ $\mathrm{NaCl}$ solution containing $10 \%$ of DMSO. The animals received a single intraperitoneal injection of $0.2 \mathrm{ml}$ of the dendrimer solution. In total, ten different dendrimer doses were tested for toxicity: $62.5 \mathrm{mg} / \mathrm{kg} ; 125 \mathrm{mg} / \mathrm{kg} ; 187.5 \mathrm{mg} / \mathrm{kg} ; 250 \mathrm{mg} / \mathrm{kg}$; 375 mg/kg; 500 mg/kg; 750 mg/kg; 1,000 mg/kg; 1,250 mg/kg; and $1,500 \mathrm{mg} / \mathrm{kg}$. The general health of mice and their behavior were monitored for 30 days following the injection. All changes were recorded on a daily basis. The animals who did not survive the experiment were necropsied and their internal organs were examined. Thirty days after the injection, the rest of the mice were euthanized by cervical dislocation. Acute toxicity of the studied compound was assessed based on the number of animals who died during the experiment, the day of their death, clinical manifestations of the intoxication, changes in behavior, and macroscopic examination of the organs and tissues conducted post-mortem [26-28]. Toxic doses were calculated in BioStat Pro 2008 5.0.1 (AnalystSoft; USA).

Biodistribution of the synthesized ${ }^{188} \mathrm{RE}-\mathrm{NP}$ was compared to that of ${ }^{188}$ Re sodium perrhenate in animals with subcutaneously transplanted LLC1 cells from the collection of cancer cell lines of Blokhin National Medical Research Center of Oncology, Russia. The choice of the cell line was dictated by the fact that the $\alpha v \beta 3$ receptor, which is an RGD-binding integrin, has been reported to homogenously distribute in the LLC1 tumor [29]. Male C57Bl/6 mice weighing 19-21 g were divided into groups of 6 . The suspension of cancer cells (4, 000, 000 cells per animal) was transplanted subcutaneously in the right thigh of each mouse. On day 10 following the inoculation, the mice received $0.2 \mathrm{ml}$ of ${ }^{188} \mathrm{RE}-\mathrm{NP}(1.85 \mathrm{MBq}$ per mouse, or $92.5 \mathrm{MBq} / \mathrm{kg}$ ) injected intravenously. The mice were decapitated 1, 3, 6, 9, 13, and $24 \mathrm{~h}$ after the ${ }^{188} \mathrm{RE}-\mathrm{NP}$ injection. Tissue and arterial blood samples were collected during autopsy. Radioactivity of the injected doses was determined using the dose calibrator ISOMED 2010 (MED Nuklear-Medizintechnik Dresden GmbH; Germany). Distribution of ${ }^{188} \mathrm{RE}-\mathrm{NP}$ in the biological tissue of mice was studied by direct radiometric measurements. The emitted radiation was measured by WIZARD 2480 scintillation

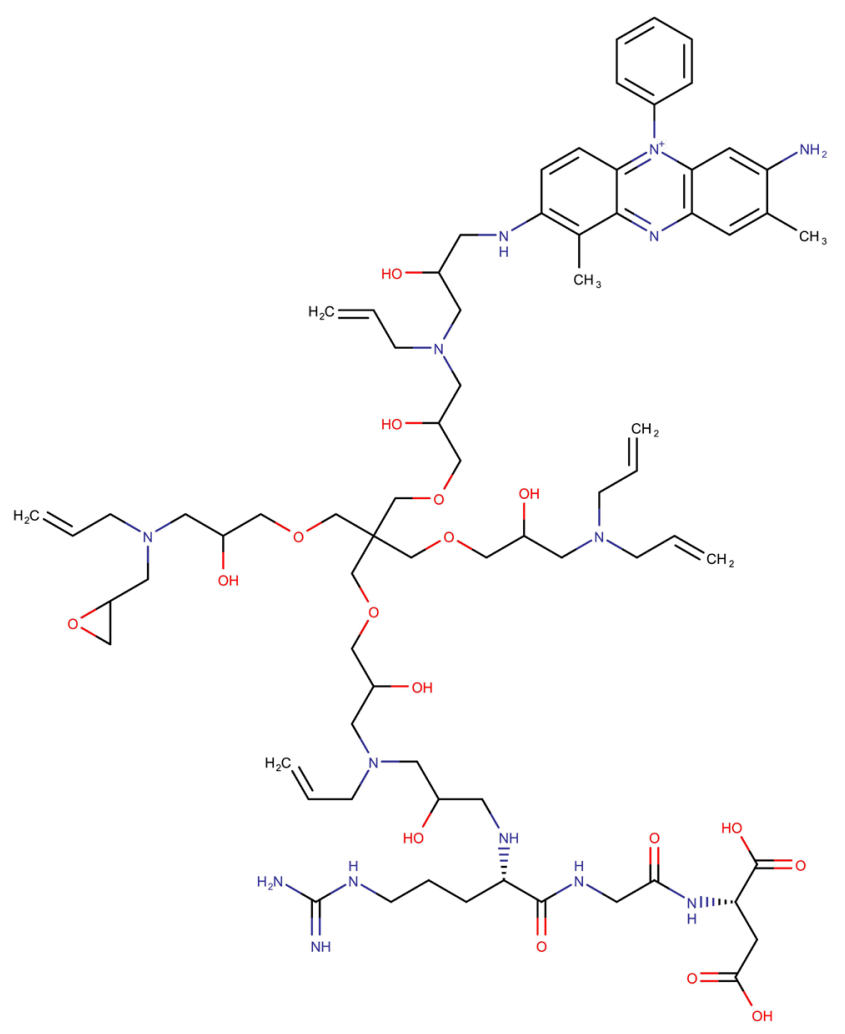

Fig. 1. The nanoplatform based on the dendrimer conjugated to the RGD peptide 
gamma-counter (Perkin Elmer; USA). ${ }^{188}$ RE-NP accumulation was evaluated based on the amount of ${ }^{188} \mathrm{Re}$ in $1 \mathrm{~g}$ of the tissue/organ relative to its injected amount.

The therapeutic efficacy of ${ }^{188} \mathrm{RE}-\mathrm{NP}$ was tested in male C57Bl/6 mice weighing 20-22 g. The mice were distributed into groups of 8 . Two days after the subcutaneous transplantation of the LLC1 cells, the mice received single $0.2 \mathrm{ml}$ doses of ${ }^{188} \mathrm{Re}$ sodium perrhenate and ${ }^{188} \mathrm{RE}-\mathrm{NP}$ in $0.9 \% \mathrm{NaCl}$ solution. The following ${ }^{188} \mathrm{Re}$ doses were studied for their therapeutic effect: $15 \mathrm{MBq} / \mathrm{kg}, 92.5 \mathrm{MBq} / \mathrm{kg}$, and $185 \mathrm{MBq} / \mathrm{kg}(0.3 \mathrm{MBq}, 1.85 \mathrm{MBq}$, and $3.7 \mathrm{MBq}$ per animal, respectively). The control group received $0.2 \mathrm{ml}$ of $0.9 \% \mathrm{NaCl}$ solution. The size and volume of tumors were measured on a daily basis throughout the experiment. The T/C value (a standard indicator of a tumoricidal effect) was calculated for the control and experimental groups using the equation [30]:

$$
\mathrm{T} / \mathrm{C}=100 \cdot V_{\text {exper }} / V_{\text {contr' }}
$$

where $V_{\text {exper }}$ is an average tumor volume in the experimental group and $V_{\text {contr }}$ is an average tumor volume in the control group.

The data were analyzed in OriginPro 8.0 (OriginLab; USA) and Excel 2003 (Microsoft; USA). Statistical significance of the obtained results was tested using the nonparametric MannWhitney $U$ test; differences were considered significant at $p \leq 0.05$.

\section{RESULTS}

The acute toxicity of the studied compound was assessed based on the number of animals who did not survive the experiment and the day of their death following the dendrimer injection. We found that the lowest lethal dose of the dendrimer was $500 \mathrm{mg} / \mathrm{kg}$; it killed 2 of 6 animals. Four of six mice died at a dose of $1,000 \mathrm{mg} / \mathrm{kg}$. A dose of $1,500 \mathrm{mg} / \mathrm{kg}$ was lethal

Table 1. Dynamics of ${ }^{188} \mathrm{Re}-\mathrm{NP}$ and ${ }^{188} \mathrm{Re}$ accumulation in the organs and tissues of mice with subcutaneously transplanted LLC1 cells (expressed as \% from the injected amount per $1 \mathrm{~g}$ of the organ/tissue)

\begin{tabular}{|c|c|c|c|c|c|c|c|}
\hline \multirow{2}{*}{ Tissue/organ } & \multirow{2}{*}{ Compound } & \multicolumn{6}{|c|}{ Time elapsed from the injection } \\
\hline & & $1 \mathrm{~h}$ & $3 \mathrm{~h}$ & $6 \mathrm{~h}$ & $9 \mathrm{~h}$ & $12 \mathrm{~h}$ & $24 \mathrm{~h}$ \\
\hline \multirow{3}{*}{ Blood } & ${ }^{188} \mathrm{Re}-\mathrm{NP}$ & $14.90 \pm 0.20$ & $10.40 \pm 0.51$ & $7.76 \pm 0.25$ & $4.42 \pm 0.24$ & $2.31 \pm 0.20$ & $1.32 \pm 0.12$ \\
\hline & \multirow{2}{*}{${ }^{188} \mathrm{Re}$} & $15.04 \pm 0.12$ & $9.40 \pm 0.80$ & $7.36 \pm 0.20$ & $5.00 \pm 0.34$ & $2.64 \pm 0.48$ & $0.94 \pm 0.24$ \\
\hline & & $p>0.2$ & $p>0.2$ & $p>0.1$ & $p>0.1$ & $p>0.2$ & $p>0.1$ \\
\hline \multirow{3}{*}{ Liver } & ${ }^{188} \mathrm{Re}-\mathrm{NP}$ & $5.22 \pm 0.36$ & $4.09 \pm 0.13$ & $3.69 \pm 0.23$ & $3.06 \pm 0.25$ & $1.02 \pm 0.07$ & $0.07 \pm 0.01$ \\
\hline & \multirow{2}{*}{${ }^{188} \mathrm{Re}$} & $5.44 \pm 0.29$ & $4.66 \pm 0.42$ & $3.53 \pm 0.18$ & $1.98 \pm 0.51$ & $1.36 \pm 0.24$ & $0.15 \pm 0.05$ \\
\hline & & $p>0.2$ & $p>0.2$ & $p>0.2$ & $p>0.1$ & $p>0.1$ & $p>0.1$ \\
\hline \multirow{3}{*}{ Kidneys } & ${ }^{188} \mathrm{Re}-\mathrm{NP}$ & $7.27 \pm 0.42$ & $5.04 \pm 0.21$ & $4.47 \pm 0.29$ & $3.32 \pm 0.35$ & $1.84 \pm 0.19$ & $0.35 \pm 0.07$ \\
\hline & \multirow{2}{*}{${ }^{188} \mathrm{Re}$} & $7.34 \pm 0.46$ & $5.35 \pm 0.56$ & $3.67 \pm 0.35$ & $2.08 \pm 0.41$ & $1.44 \pm 0.25$ & $0.35 \pm 0.07$ \\
\hline & & $p>0.8$ & $p>0.5$ & $p>0.1$ & $p>0.1$ & $p>0.1$ & $p>0.6$ \\
\hline \multirow{3}{*}{ Lungs } & ${ }^{188} \mathrm{Re}-\mathrm{NP}$ & $10.01 \pm 0.50$ & $7.46 \pm 0.31$ & $5.68 \pm 0.16$ & $4.61 \pm 0.32$ & $2.75 \pm 0.23$ & $0.34 \pm 0.06$ \\
\hline & \multirow{2}{*}{${ }^{188} \mathrm{Re}$} & $10.09 \pm 0.50$ & $7.79 \pm 0.52$ & $5.52 \pm 0.26$ & $3.31 \pm 0.38$ & $1.99 \pm 0.33$ & $0.30 \pm 0.05$ \\
\hline & & $p>0.5$ & $p>0.2$ & $p>0.3$ & $p>0.1$ & $p>0.1$ & $p>0.2$ \\
\hline \multirow{3}{*}{ Spleen } & ${ }^{188} \mathrm{Re}-\mathrm{NP}$ & $9.77 \pm 1.17$ & $7.66 \pm 0.43$ & $4.74 \pm 0.35$ & $4.15 \pm 0.30$ & $2.16 \pm 0.06$ & $0.29 \pm 0.05$ \\
\hline & \multirow{2}{*}{${ }^{188} \mathrm{Re}$} & $9.52 \pm 0.40$ & $6.90 \pm 0.37$ & $4.72 \pm 0.47$ & $3.01 \pm 0.20$ & $1.95 \pm 0.33$ & $0.31 \pm 0.11$ \\
\hline & & $p>0.8$ & $p>0.1$ & $p>0.8$ & $p>0.1$ & $p>0.2$ & $p>0.8$ \\
\hline \multirow{3}{*}{ Femoral bone } & ${ }^{188} \mathrm{Re}-\mathrm{NP}$ & $5.61 \pm 5.61$ & $3.77 \pm 3.77$ & $3.14 \pm 3.14$ & $2.13 \pm 2.13$ & $1.45 \pm 1.45$ & $0.44 \pm 0.44$ \\
\hline & \multirow{2}{*}{${ }^{188} \mathrm{Re}$} & $5.02 \pm 0.29$ & $3.98 \pm 0.38$ & $2.77 \pm 0.21$ & $1.58 \pm 0.06$ & $1.11 \pm 0.09$ & $0.44 \pm 0.05$ \\
\hline & & $p>0.1$ & $p>0.5$ & $p>0.1$ & $p>0.1$ & $p>0.1$ & $p>0.8$ \\
\hline \multirow{3}{*}{ Tumor } & ${ }^{188} \mathrm{Re}-\mathrm{NP}$ & $8.16 \pm 0.26$ & $8.20 \pm 0.14$ & $8.24 \pm 0.06$ & $6.54 \pm 0.35$ & $3.15 \pm 0.35$ & $1.17 \pm 0.07$ \\
\hline & \multirow{2}{*}{${ }^{188} \mathrm{Re}$} & $6.06 \pm 0.17$ & $3.82 \pm 0.26$ & $2.32 \pm 0.42$ & $1.90 \pm 0.16$ & $1.14 \pm 0.09$ & $0.66 \pm 0.07$ \\
\hline & & $p<0.03$ & $p<0.01$ & $p<0.01$ & $p<0.01$ & $p<0.05$ & $p<0.05$ \\
\hline
\end{tabular}

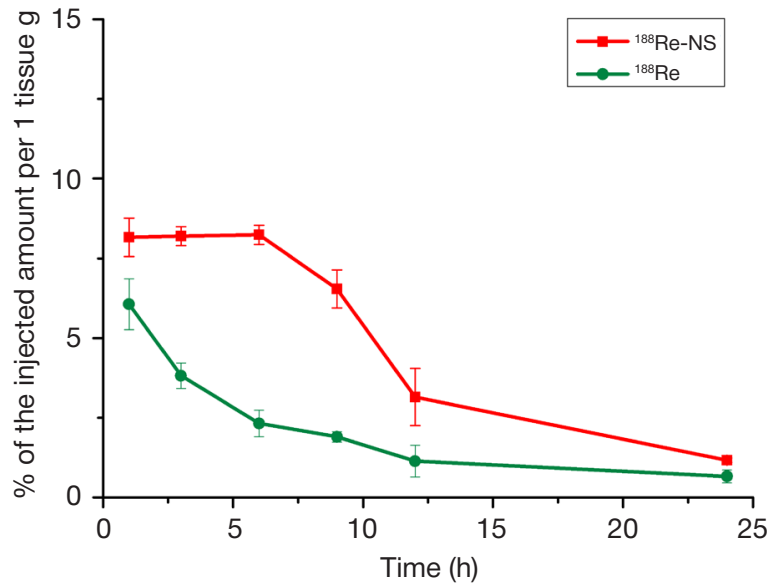

Fig. 2. Dynamics of ${ }^{188} \mathrm{Re}-\mathrm{NP}$ and ${ }^{188} \mathrm{Re}$ accumulation (\% of the injected amount per $1 \mathrm{~g}$ of tissue) in the subcutaneously transplanted LLC1male in male C57BI/6 mice 
for the entire group. Lethal dendrimer doses caused transient motor excitation for the first 30 min that subsequently turned into sopor. The mice died within 144 hours after the injection depending on the dose of the dendrimer. A transient loss of weight (5-8\%) and increased motor activity were observed in the surviving mice during the first 5 days following the injection. Necropsy revealed no visible signs of pathology in the heart, kidneys, spleen, and lungs of the animals; no visible pathology or hyperthermia were observed in the peritoneum; the liver was enlarged and its edges were blunt. The sublethal doses of the dendrimer did not induce any visible changes in the behavior or general health of mice: no ataxia or local paresis were observed. The mice were gaining weight at the rate of the control group. Their skin condition was normal. No macroscopic changes were noticed in the internal organs during autopsy. Based on the number of dead animals in each of 10 experimental groups, toxic dendrimer doses were calculated for mice: $L_{10}=270 \pm$ $92 \mathrm{mg} / \mathrm{kg} ; \mathrm{LD}_{16}=382 \pm 94 \mathrm{mg} / \mathrm{kg} ; \mathrm{LD}_{50}=779 \pm 111 \mathrm{mg} / \mathrm{kg}$; $\mathrm{LD}_{84}=1177 \pm 196 \mathrm{mg} / \mathrm{kg} ; \mathrm{LD}_{90}=1289 \pm 260 \mathrm{mg} / \mathrm{kg} ; \mathrm{LD}_{100}=$ $1376 \pm 367 \mathrm{mg} / \mathrm{kg}$.

Table 1 compares the dynamics of ${ }^{188} \mathrm{RE}-\mathrm{NP}$ and ${ }^{188} \mathrm{Re}$-sodium perrhenate accumulation over time in mice with subcutaneously transplanted LLC1 carcinoma. The only significant difference was revealed for drug accumulation in the tumor, in contrast to healthy tissue. The dynamics of ${ }^{188} \mathrm{Re}-\mathrm{NP}$ and ${ }^{188} \mathrm{Re}$-sodium perrhenate accumulation in LLC1 are presented in Fig. 2

Because ${ }^{188} \mathrm{Re}-\mathrm{NP}$ is intended for anticancer radiation therapy, its tumor-to-normal uptake is an important pharmacokinetic characteristic. Calculated tumor-to-normal ratio $(\mathrm{T} / \mathrm{N})$ values for the most important organs are shown in Table 2. In the case of ${ }^{188} \mathrm{Re}-\mathrm{NP}$, the T/N value was $>1$ for almost all organs and tissues $3 \mathrm{~h}$ after the injection. This indicates more vigorous clearance of the substance from healthy organs than from the tumor. The rate of ${ }^{188} \mathrm{Re}$ clearance from the tumor was comparable to that measured for the liver and the femoral bone.

The therapeutic efficacy of ${ }^{188} \mathrm{Re}-\mathrm{NP}$ was being studied for 30 days following tumor transplantation. A single injection of the compound produced a marked tumoricidal effect $(p<0.05)$ throughout the entire observation period only at doses of $185 \mathrm{MBq} / \mathrm{kg}$ (Table 3, Fig. 3). Single doses of ${ }^{188} \mathrm{Re}-$ sodium perrhenate taken at $185 \mathrm{MBq} / \mathrm{kg}$ had no therapeutic effect at all (Fig. 4). The T/C values for the studied ${ }^{188}$ Re doses are presented in Table 3.

The observed tumoricidal effect was dose-dependent. It was significant at a ${ }^{188} \mathrm{Re}-\mathrm{NP}$ dose of $185 \mathrm{MBq} / \mathrm{kg}$, weak at $92.5 \mathrm{MBq} / \mathrm{kg}$, and insignificant at $15 \mathrm{MBq} / \mathrm{kg}$. The minimal effective therapeutic concentration of ${ }^{188} \mathrm{Re}-\mathrm{NP}$ was determined based on the curves demonstrating the dynamics of tumor growth.

\section{DISCUSSION}

This study shows that the toxicity of the proposed dendrimer is comparable to the toxicity of its analogs from the same class of compounds [31].

Our findings suggest that ${ }^{188} \mathrm{Re}-\mathrm{NP}$ taken up by the tumor is retained there for up to 6 hours following the injection. During this time period, the amount of ${ }^{188} \mathrm{Re}-\mathrm{NP}$ in the tumor remains high, making $8.2 \%$ of the injected amount. This may indicate the stability of the bonds between ${ }^{188} \mathrm{Re}-\mathrm{NP}$ and the tumor tissue. The dynamics of ${ }^{188}$ Re sodium perrhenate accumulation does not follow the same pattern. The maximum ratio of ${ }^{188} \mathrm{Re}-\mathrm{NP}$ to ${ }^{188}$ Re sodium perrhenate uptake by the tumor was $3.55 \pm 0.660$ 6 hours after the injection.

The ${ }^{188} \mathrm{Re}-\mathrm{NP}$ dose of $185 \mathrm{MBq} / \mathrm{kg}$ at which the most significant tumoricidal effect was observed in mice was converted to a human dose equivalent of $15.42 \mathrm{MBq} / \mathrm{kg}$. This is lower than the standard doses of radiopharmaceutical agents used in radiation therapy (44-47 MBq/kg) [32]. Consequently, the effective radiation dose can be reduced if ${ }^{188} \mathrm{Re}-\mathrm{NP}$ is used as a radiopharmaceutical agent. Another advantage of the proposed platform is its low toxicity. The studied substance was taken at 100-fold excess to ensure the complete binding of ${ }^{188} \mathrm{Re}$; the concentration of NP at $185 \mathrm{MBq} / \mathrm{kg}$ was

Table 2. Comparison of tumor-to-normal uptake ratio of ${ }^{188} \mathrm{Re}-\mathrm{NP}$ and ${ }^{188} \mathrm{Re}$ by the organs and tissues of experimental mice

\begin{tabular}{|c|c|c|c|c|c|c|c|}
\hline \multirow{2}{*}{ Tissue/organ } & \multirow{2}{*}{ Compound } & \multicolumn{6}{|c|}{ Time elapsed from the injection } \\
\hline & & $1 \mathrm{~h}$ & $3 \mathrm{~h}$ & $6 \mathrm{~h}$ & $9 \mathrm{~h}$ & $12 \mathrm{~h}$ & $24 \mathrm{~h}$ \\
\hline \multirow{3}{*}{ Tumor/blood } & ${ }^{188} \mathrm{Re}-\mathrm{NP}$ & $0.55 \pm 0.02$ & $0.79 \pm 0.04$ & $1.06 \pm 0.04$ & $1.48 \pm 0.04$ & $1.36 \pm 0.06$ & $0.89 \pm 0.11$ \\
\hline & \multirow{2}{*}{${ }^{188} \mathrm{Re}$} & $0.40 \pm 0.01$ & $0.41 \pm 0.06$ & $0.32 \pm 0.07$ & $0.38 \pm 0.05$ & $0.45 \pm 0.11$ & $0.72 \pm 0.18$ \\
\hline & & $p>0.1$ & $p<0.05$ & $p<0.004$ & $p<0.004$ & $p<0.004$ & $p>0.1$ \\
\hline \multirow{3}{*}{ Tumor/liver } & ${ }^{188} \mathrm{Re}-\mathrm{NP}$ & $1.57 \pm 0.14$ & $2.01 \pm 0.09$ & $2.24 \pm 0.13$ & $2.15 \pm 0.24$ & $3.09 \pm 0.29$ & $16.55 \pm 2.7$ \\
\hline & \multirow{2}{*}{${ }^{188} \mathrm{Re}$} & $1.11 \pm 0.04$ & $0.82 \pm 0.02$ & $0.66 \pm 0.14$ & $1.02 \pm 0.37$ & $0.86 \pm 0.19$ & $4.65 \pm 1.25$ \\
\hline & & $p<0.05$ & $p<0.004$ & $p<0.001$ & $p<0.004$ & $p<0.001$ & $p<0.001$ \\
\hline \multirow{3}{*}{ Tumor/kidneys } & ${ }^{188} \mathrm{Re}-\mathrm{NP}$ & $1.12 \pm 0.07$ & $1.63 \pm 0.04$ & $1.85 \pm 0.11$ & $1.99 \pm 0.22$ & $1.73 \pm 0.30$ & $3.42 \pm 0.85$ \\
\hline & \multirow{2}{*}{${ }^{188} \mathrm{Re}$} & $0.83 \pm 0.07$ & $0.72 \pm 0.08$ & $0.63 \pm 0.09$ & $0.95 \pm 0.27$ & $0.81 \pm 0.19$ & $1.91 \pm 0.15$ \\
\hline & & $p<0.004$ & $p<0.004$ & $p<0.004$ & $p<0.004$ & $p<0.05$ & $p<0.05$ \\
\hline \multirow{3}{*}{ Tumor/lungs } & ${ }^{188} \mathrm{Re}-\mathrm{NP}$ & $0.82 \pm 0.06$ & $1.10 \pm 0.06$ & $1.45 \pm 0.05$ & $1.43 \pm 0.17$ & $3.86 \pm 0.80$ & $13.92 \pm 2.56$ \\
\hline & \multirow{2}{*}{${ }^{188} \mathrm{Re}$} & $0.60 \pm 0.04$ & $0.49 \pm 0.05$ & $0.42 \pm 0.09$ & $0.58 \pm 0.10$ & $0.59 \pm 0.14$ & $2.18 \pm 0.17$ \\
\hline & & $p<0.05$ & $p<0.004$ & $p<0.004$ & $p<0.004$ & $p<0.02$ & $p<0.002$ \\
\hline \multirow{3}{*}{ Tumor/spleen } & ${ }^{188} \mathrm{Re}-\mathrm{NP}$ & $0.84 \pm 0.11$ & $1.07 \pm 0.04$ & $1.75 \pm 0.12$ & $1.58 \pm 0.05$ & $1.46 \pm 0.12$ & $4.09 \pm 0.80$ \\
\hline & \multirow{2}{*}{${ }^{188} \mathrm{Re}$} & $0.64 \pm 0.04$ & $0.55 \pm 0.02$ & $0.49 \pm 0.04$ & $0.63 \pm 0.08$ & $0.60 \pm 0.14$ & $2.26 \pm 0.64$ \\
\hline & & $p<0.05$ & $p<0.004$ & $p<0.004$ & $p<0.004$ & $p<0.004$ & $p<0.004$ \\
\hline \multirow{3}{*}{ Tumor/femoral bone } & ${ }^{188} \mathrm{Re}-\mathrm{NP}$ & $1.46 \pm 0.10$ & $2.17 \pm 0.01$ & $2.64 \pm 0.23$ & $3.08 \pm 0.22$ & $2.18 \pm 0.32$ & $2.67 \pm 0.15$ \\
\hline & \multirow{2}{*}{${ }^{188} \mathrm{Re}$} & $1.21 \pm 0.10$ & $0.97 \pm 0.13$ & $0.85 \pm 0.21$ & $1.20 \pm 0.14$ & $1.04 \pm 0.14$ & $1.51 \pm 0.31$ \\
\hline & & $p<0.05$ & $p<0.004$ & $p<0.004$ & $p<0.004$ & $p<0.05$ & $p<0.004$ \\
\hline \multicolumn{2}{|c|}{ Tumor ${ }^{188} \mathrm{Re}-\mathrm{NP} /$ Tumor ${ }^{188} \mathrm{Re}$} & $1.35 \pm 0.05$ & $2.15 \pm 0.19$ & $3.55 \pm 0.66$ & $3.45 \pm 0.32$ & $2.76 \pm 0.51$ & $1.79 \pm 0.24$ \\
\hline
\end{tabular}


Table 3. The therapeutic effect of the ${ }^{188}$ Re-NP against the LLC1 carcinoma

\begin{tabular}{|l|c|c|c|c|c|c|c|c|c|}
\hline Time elapsed from the injection, days & \multicolumn{3}{|c|}{7 days } & \multicolumn{3}{c|}{14 days } & \multicolumn{3}{c|}{18 days } \\
\hline The dose of ${ }^{188} \mathrm{Re}, \mathrm{MBq} / \mathrm{kg}$ & 15 & 92.5 & 185 & 15 & 92.5 & 185 & 15 & 92.5 & 185 \\
\hline T/C, $\%$ & 100 & 41 & 5 & 74 & 55 & 13 & 87 & 75 & 20 \\
\hline
\end{tabular}

Note: The table shows the results of therapeutic efficacy assessment on days 7, 14 and 18 after drug administration.

A

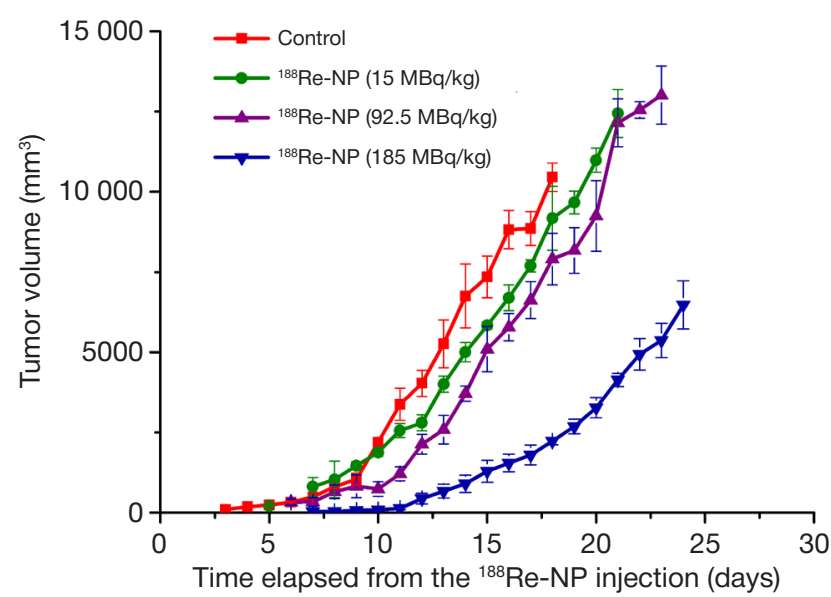

B

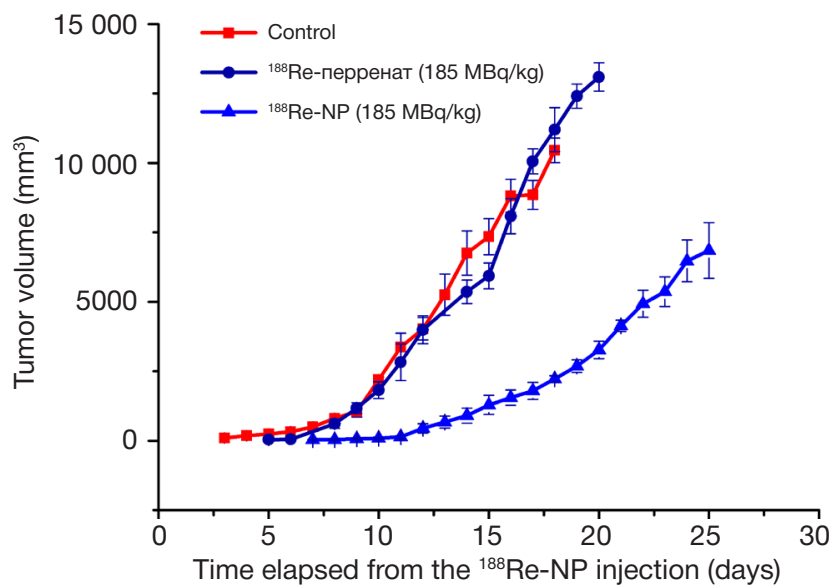

Fig. 3. The growth dynamics of the subcutaneously transplanted LLC1 tumor in C57BI/6 mice following a single injection of ${ }^{188} \mathrm{Re}-\mathrm{NP}$ taken at different ${ }^{188}$ Re doses (A) and a single injection of ${ }^{188}$ Re sodium perrhenate and ${ }^{188} \mathrm{Re}-\mathrm{NP}\left({ }^{188} \mathrm{Re}\right.$ dose $\left.=185 \mathrm{MBq} / \mathrm{kg}\right)(\mathbf{B})$

$4.05 \cdot 10^{-3} \mathrm{mg} / \mathrm{kg}$ (or $2.16 \cdot 10^{-3} \mathrm{mg} / \mathrm{kg}$ of the dendrimer), which is lower than $L D_{10}$ by 5 orders of magnitude. Our findings suggest that the proposed NP may hold promise as a potent radiopharmaceutical.

\section{CONCLUSIONS}

This study demonstrates the feasibility of the proposed dendrimer-based platform for targeted drug delivery of tumoricidal agents. We have established the minimally effective therapeutic dose of ${ }^{188} \mathrm{Re}$ in the studied compound and revealed that the synthesized dendrimer exhibits dosedependent activity against tumor cells. Acute toxicity tests conducted in mice have shown that the ${ }^{188} \mathrm{Re}-\mathrm{NP}$ platform is lowly toxic and ensures a considerable tumoricidal effect at doses much lower than $\mathrm{LD}_{10}$. The levels of ${ }^{188} \mathrm{Re}-\mathrm{NP}$ accumulation in the tumor, as well as the value of the $\mathrm{T} / \mathrm{N}$ ratio, lead us to conclude that the compound can be safely used to enhance the therapeutic dose of $\beta$-radiation in the tumor. The ${ }^{188} \mathrm{Re}$ component of the ${ }^{188} \mathrm{Re}-\mathrm{NP}$ composition taken at a dose of $185 \mathrm{Mbq} / \mathrm{kg}$ induces a marked tumoricidal effect 18 days following its administration.

\section{Литература}

1. Kulakov VN, Lipengolts AA, Grigorieva EY, Shimanovskii NL. Pharmaceuticals for Binary Radiotherapy and Their Use for Treatment of Malignancies (A Review). Pharm Chem J. 2016 Sep 8; 50 (6): 388-93.

2. Rakesh Kumar Tekade, Palanirajan Vijayaraj Kumar, Narendra Kumar Jain. Dendrimers in Oncology: An Expanding Horizon. Chem Rev. 2009; 109: 49-87.

3. Wu L-P, Ficker M, Christensen JB. Dendrimers in Medicine: Therapeutic Concepts and Pharmaceutical Challenges. Bioconjugate Chem. 2015; 26: 1198-211.

4. Olson ES, Jiang T, Aguilera T, Nguyen QT, Ellies LG, Scadeng M, et al. Activatable cell penetrating peptides linked to nanoparticles as dual probes for in vivo fluorescence and MR imaging of proteases. Proc Natl Acad Sci. 2010; 107 (9): 4311-6.

5. Palmerston Mendes L, Pan J, Torchilin V. Dendrimers as Nanocarriers for Nucleic Acid and Drug Delivery in Cancer Therapy. Molecules. 2017; 22 (9): 1401.

6. Xu L, Yeudall WA, Yang H. Folic acid-decorated polyamidoamine dendrimer exhibits high tumor uptake and sustained highly localized retention in solid tumors: Its utility for local siRNA delivery. Acta Biomater. 2017; (57): 251-61.

7. Stukalov YuV, Grigorieva EYu, Kulakov VN, Baryshnikov AYu. Transport platform synthesis for drug development. Pharmaceutical chemistry journal. 2017; 51 (6): 480-1.

8. Григорьева Е. Ю., Стукалов Ю. В., Смирнова А. В., Колдаева Е. Ю., Калыгина Н. С., Кулаков В. Н. и др. Цитотоксическое действие конструкций на основе дендримеров с 188Re c моноклональными антителами антиICO-25 (MUC1) и анти-ICO-80 (CD5) На моделях клеточных линий SKOV-3 (рак яичника) и Jurkat (Т-лимфобластная лимфома). Химико-фармацевтический журнал. 2018; 52 (8): 3-6.

9. Григорьева Е. Ю., Стукалов Ю. В., Колдаева Е. Ю. Конструкции на основе дендримеров нового класса для таргетной радиотерапии онкологических заболеваний. Российский биотерапевтический журнал. 2009; 8 (1): 5-6.

10. Domingo-Espín J, Petegnief V, de Vera N. RGD-based cell ligands for cell-targeted drug delivery act as potent trophic factors. Nanomedicine: Nanotechnology, Biology, and Medicine. 2012; (8): 1263-6.

11. Берман А. Е., Козлова Н. И., Морозевич Г. Е. Интегрины как потенциальная мишень для целевой терапии рака. Биомедицинская химия. 2013; 59 (3): 239-48.

12. Miller LM, Pritchard JM, Macdonald SJF, Jamieson C, Watson AJB. The Emergence of Small Molecule Non-RGD-mimetic Inhibitors for RGD Integrins Journal of Medicinal Chemistry. 2017; 60 (8): 3241-51.

13. Hwang R, Varner J. The role of integrins in tumor angiogenesis. Hematol Oncol Clin North Am. 2004; 18 (5): 991-1006. 
14. Koistinen $\mathrm{P}$, Ahonen M, Kähäri VM, Heino J. AlphaV integrin promotes in vitro and in vivo survival of cells in metastatic melanoma. Int J Cancer. 2004; 112 (1): 61-70.

15. Kuphal S, Bauer R, Bosserhoff AK. Integrin signaling in malignant melanoma. Cancer Metastasis Rev. 2005; 24 (2): 195-222.

16. Veeravagu A, Liu Z, Niu G, Chen K, Jia B, Cai W et al. Integrin alphavbeta3-targeted radioimmunotherapy of glioblastoma multiforme. Clin Cancer Res. 2008; (14): 7330-9.

17. Landen CN, Kim TJ, Lin YG, Merritt WM, Kamat AA, Han LY et al. Tumour-selective response to antibody-mediated targeting of alphavbeta3 integrin in ovarian cancer. Neoplasia. 2008; 10 (11): 1259-67.

18. Beiki D, Tajik M, Haddad P, Fallahi B, Arefpour AM, Mirzaei H et al. Effectiveness and complications of 188Re-HEDP in palliative treatment of diffuse skeletal metastases. Iran J Nucl Med. 2015; 23 (1): 44-8.

19. Erfani M, Doroudi A, Dinari MA, Shirmardi SP. Preparation of a rhenium-188 labeled bisphosphonate for bone pain palliation therapy. Journal of Radioanalytical and Nuclear Chemistry. 2015; 303 (3): 2027-32

20. Zamora PO, Gulhke S, Bender H. Experimental radiotherapy of receptor-positive human prostate adenocarcinoma with $188 \mathrm{Re}$ RC-160, a directly-radiolabeled somatostatin analogue. Int J Cancer. 1999; (6): 214-20.

21. Molina-Trinidad EM, Arteaga de Murphy C, Ferro-Flores G. Radiopharmacokinetic and dosimetric parameters of $188 \mathrm{Re}$ lanreotide in athymic mice with induced human cancer tumors. Int J Pharm. 2006; (310): 125-30.

22. Krylov V, Kochetova T, Smolyarchuk M, Petriev V, Kanygin V Alexandrova A et al. Evaluation of 188Re-khedp (phosphoren) for palliative treatment in patients with bone metastases., World Journal of Nuclear Medicine. 2013; 12 (2): 255-6.

23. Kochetova T, Smolyarchuk M, Krylov V, Voloznev V, Lunev A,
Petriev VM. 188Re-zoledronic acid: first in man study. World Journal of Nuclear Medicine. 2013; 12 (2): 228-9.

24. Konior M, Iller E. Classic Radionuclide 188W/188Re Generato (Experiments, Design and Construction). Mod Chem appl. 2014; (2): 143.

25. Европейская конвенция по защите позвоночных животных, используемых для экспериментальных и других научных целей, ЕЭС, Страсбург, 1985 г. Ланималогия. 1993; (1): 29 с.

26. Беленький М. Л. Элементы количественной оценки фармакологического эффекта: Л.: Изд-во «МедГиз», 1968; 151 с.

27. Гуськова Т. А. Токсикология лекарственных средств: М.: Издво «Русский врач», 2003; 154 с

28. Трахтенберг И. А., Сова А. Е., Шефтель В. О., Оникиенко Ф. А. Проблема нормы в токсикологии. М.: Изд-во «Медицина», 1992; 208 c.

29. Seguin J, Nicolazzi C, Mignet N, Scherman D, Chabot GG Vascular density and endothelial cell expression of integrin alpha $\checkmark$ beta 3 and E-selectin in murine tumours. Tumour Biol. 2012; 33 (5): 1709-17

30. Трещалина Е. М., Жукова О. С., Герасимова Г. К., Андронова Н. В. и др. Методические рекомендации по доклиническому изучению противоопухолевой активности лекарственных средств. В книге: Миронов А. Н., Бунатян Н. Д. и др., редакторы. Руководство по проведению доклинических исследований лекарственных средств. М.: Гриф и К., 2012; с. 642-657

31. Колдаева Е. Ю., Григорьева Е. Ю., Стукалов Ю. В Сравнительная токсикология наноконструкций на основе дендримеров для таргетной радиотерапии в онкологии Российский биотерапевтический журнал. 2010; 9 (3): 13-14.

32. Argyrou M, Valassi A, Andreou M, Lyra M. Rhenium-188 Production in Hospitals, by W-188/Re-188 Generator, for Easy Use in Radionuclide Therapy. Int J Mol Imaging. 2013; (2013): 1-7.

\section{References}

1. Kulakov VN, Lipengolts AA, Grigorieva EYu, Shimanovskii NL. Pharmaceuticals for Binary Radiotherapy and Their Use for Treatment of Malignancies (A Review). Pharm Chem J. 2016 Sep 8; 50 (6): 388-93.

2. Rakesh Kumar Tekade, Palanirajan Vijayaraj Kumar, Narendra Kumar Jain. Dendrimers in Oncology: An Expanding Horizon. Chem Rev. 2009; 109: 49-87.

3. Wu L-R, Ficker M, Christensen JB. Dendrimers in Medicine: Therapeutic Concepts and Pharmaceutical Challenges. Bioconjugate Chem. 2015; 26: 1198-211.

4. Olson ES, Jiang T, Aguilera T, Nguyen QT, Ellies LG, Scadeng M et al. Activatable cell penetrating peptides linked to nanoparticles as dual probes for in vivo fluorescence and MR imaging of proteases. Proc Natl Acad Sci. 2010; 107 (9): 4311-6.

5. Palmerston Mendes L, Pan J, Torchilin V. Dendrimers as Nanocarriers for Nucleic Acid and Drug Delivery in Cancer Therapy. Molecules. 2017; 22 (9): 1401.

6. $\mathrm{Xu} L$, Yeudall WA, Yang $\mathrm{H}$. Folic acid-decorated polyamidoamine dendrimer exhibits high tumor uptake and sustained highly localized retention in solid tumors: Its utility for local siRNA delivery. Acta Biomater. 2017; (57): 251-61.

7. Stukalov YuV, Grigorieva EYu, Kulakov VN, Baryshnikov AYu Transport platform synthesis for drug development. Pharmaceutical chemistry journal. 2017; 51 (6): 480-1.

8. Grigorieva EYu, Stukalov YV, Smirnova AV, Koldaeva EY, Kalygina NS, Kulakov VN et al. Cytotoxicity of Conjugates of 188Re-Labeled Dendrimers and Monoclonal Antibodies AntiICO-25 (MUC1) and Anti-ICO-80 (CD5) Against SKOV-3 (Ovary Cancer) and Jurkat Tumor Cell Lines (T-Lymphoblstic Lymphoma). Pharm Chem J. 2018; 52 (8): 681-4.

9. Grigorieva EYu, Stukalov YuV, Koldaeva EYu. Konstruktsii na osnove dendrimerov novogo klassa dlya targetnoy radioterapi onkologicheskikh zabolevaniy. Rossiyskiy bioterapevticheskiy zhurnal. 2009; 8 (1): 5-6. Russian.
10. Domingo-Espín J, Petegnief V, de Vera N. RGD-based cell ligands for cell-targeted drug delivery act as potent trophic factors. Nanomedicine: Nanotechnology, Biology, and Medicine. 2012; (8): 1263-6.

11. Berman AE, Kozlova, NI, Morozevich GE. Integrins as a potentia target for targeted anticancer therapy. Biochem. Moscow Suppl Ser B. 2012; 6 (3): 205-10.

12. Miller LM, Pritchard JM, Macdonald SJF, Jamieson C, Watson AJB. The Emergence of Small Molecule Non-RGD-mimetic Inhibitors for RGD Integrins Journal of Medicinal Chemistry. 2017; 60 (8): 3241-51

13. Hwang $R$, Varner J. The role of integrins in tumor angiogenesis Hematol Oncol Clin North Am. 2004; 18 (5): 991-1006.

14. Koistinen $\mathrm{P}$, Ahonen $\mathrm{M}$, Kähäri VM, Heino J. AlphaV integrin promotes in vitro and in vivo survival of cells in metastatic melanoma. Int J Cancer. 2004; 112 (1): 61-70.

15. Kuphal S, Bauer R, Bosserhoff AK. Integrin signaling in malignant melanoma. Cancer Metastasis Rev. 2005; 24 (2): 195-222.

16. Veeravagu A, Liu Z, Niu G, Chen K, Jia B, Cai W et al. Integrin alphavbeta3-targeted radioimmunotherapy of glioblastoma multiforme. Clin Cancer Res. 2008; (14): 7330-9.

17. Landen CN, Kim TJ, Lin YG, Merritt WM, Kamat AA, Han LY et al. Tumour-selective response to antibody-mediated targeting of alphavbeta3 integrin in ovarian cancer. Neoplasia. 2008; 10 (11): 1259-67.

18. Beiki D, Tajik M, Haddad P, Fallahi B, Arefpour AM, Mirzaei H et. al. Effectiveness and complications of 188Re-HEDP in palliative treatment of diffuse skeletal metastases. Iran J Nucl Med. 2015; 23 (1): 44-8.

19. Erfani M, Doroudi A, Dinari MA, Shirmardi SP. Preparation of a rhenium-188 labeled bisphosphonate for bone pain palliation therapy. Journal of Radioanalytical and Nuclear Chemistry. 2015; 303 (3): 2027-32

20. Zamora PO, Gulhke S, Bender H. Experimental radiotherapy of 
receptor-positive human prostate adenocarcinoma with $188 \mathrm{Re}$ RC-160, a directly-radiolabeled somatostatin analogue. Int $J$ Cancer. 1999; (6): 214-20.

21. Molina-Trinidad EM, Arteaga de Murphy C, Ferro-Flores G. Radiopharmacokinetic and dosimetric parameters of $188 \mathrm{Re}$ lanreotide in athymic mice with induced human cancer tumors. Int J Pharm. 2006; (310): 125-30.

22. Krylov V, Kochetova T, Smolyarchuk M, Petriev V, Kanygin V, Alexandrova $A$ et al. Evaluation of 188Re-khedp (phosphoren) for palliative treatment in patients with bone metastases., World Journal of Nuclear Medicine. 2013; 12 (2): 255-6.

23. Kochetova T, Smolyarchuk M, Krylov V, Voloznev V, Lunev A Petriev VM. 188Re-zoledronic acid: first in man study. World Journal of Nuclear Medicine. 2013; 12 (2): 228-9.

24. Konior M, Iller E. Classic Radionuclide 188W/188Re Generator (Experiments, Design and Construction). Mod Chem appl. 2014; (2): 143.

25. Evropejskaja konvencija po zashhite pozvonochnyh zhivotnyh, ispol'zuemyh dlja jeksperimental'nyh i drugih nauchnyh celej, EJeS, Strasburg, 1985 g. Lanimalogija. 1993; (1): 29 s.

26. Belenkiy ML. Jelementy kolichestvennoj ocenki farmakologicheskogo jeffekta: L.: Izd-vo «MedGiz», 1968; 151 s.
27. Guskova TA. Toksikologiya lekarstvennyh sredstv: M.: Izd-vo «Russkij vrach», 2003; 154 s.

28. Trahtenberg IA, Sova AE, Sheftel VO, Onikienko FA. Problema normy v toksikologii. M.: Izd-vo «Medicina», 1992; 208 s.

29. Seguin J, Nicolazzi C, Mignet N, Scherman D, Chabot GG. Vascular density and endothelial cell expression of integrin alpha $\checkmark$ beta 3 and E-selectin in murine tumours. Tumour Biol. 2012; 33 (5): 1709-17.

30. Treshhalina EM, Zhukova OS, Gerasimova GK, Andronova NV i dr. Metodicheskie rekomendacii po doklinicheskomu izucheniju protivoopuholevoj aktivnosti lekarstvennyh sredstv. $\mathrm{V}$ knige: Mironov AN, Bunatjan ND i dr., redaktory. Rukovodstvo po provedeniju doklinicheskih issledovanij lekarstvennyh sredstv. M.: Grif i K., 2012; S. 642-657.

31. Koldaeva EYu, Grigorieva EYu, Stukalov YuV. Sravnitel'naja toksikologija nanokonstrukcij na osnove dendrimerov dlja targetnoj radioterapii $v$ onkologii. Rossijskij Bioterapevticheskij Zhurnal. 2010; 9 (3): 13-14.

32. Argyrou M, Valassi A, Andreou M, Lyra M. Rhenium-188 Production in Hospitals, by W-188/Re-188 Generator, for Easy Use in Radionuclide Therapy. Int J Mol Imaging. 2013; (2013): $1-7$. 